\title{
EKSISTENSI HAK TANGGUNGAN SEBAGAI LEMBAGA JAMINAN HAK ATAS TANAH (TINJAUAN FILOSOFIS)
}

\author{
St. Nurjannah
}

Universitas Islam Negeri (UIN) Alauddin Makassar

Email:adzan_amjah@yahoo.co.id

\begin{abstract}
Responsibility rights is charged against by guarantee rights is land right as referred to in Law of No.5 Year 1960 about Regulation Of Base Specifics of Agraria. Existence of guarantee institute (responsibility rights) very supporting in era development of economics. Especially from entrepreneur requiring credit for the development of effort him. Growth of commerce and economics followed by growth of requirement of credit and giving of credit facility will need guarantee for the shake of security [gift/ giving] of credit
\end{abstract}

Keyword : Rights Responsibility, Institute Guarantee Land right

\begin{abstract}
Abstrak
Hak tanggungan adalah hak jaminan yang dibebankan pada hak atas tanah sebagaimana dimaksud dalam Undang-Undang No.5 Tahun 1960 tentang Peraturan Dasar Pokok-Pokok Agraria. Keberadaan lembaga jaminan (hak tanggungan) sangat menunjang dalam era pembangunan ekonomi, terutama dari pengusaha yang membutuhkan kredit untuk pengembangan usahanya. Perkembangan ekonomi dan perdagangan yang diikuti oleh perkembangan kebutuhan akan kredit dan pemberian fasilitas kredit memerlukan jaminan demi keamanan pemberian kredit.
\end{abstract}

Kata Kunci : Hak Tanggungan, Lembaga Jaminan Hak Atas Tanah 


\section{PENDAHULUAN}

7 anah menempati posisi yang sangat penting dalam kerangka pembangunan sehingga tanah ditempatkan sebagai modal pembangunan. Kompleksnya masalah pertanahan yang dihadapi sekarang ini dapat menghambat proses pembangunan yang sedang berjalan, sehingga pembaruan dalam hukum pertanahan nasional kita sangat diperlukan. Lahirnya Undang-Undang Hak Tanggungan (UUHT) yaitu UU No.4 Tahun 1996 dengan judul "Undang-Undang Hak Tanggungan Atas Tanah Beserta Benda-Benda Yang Berkaitan Dengan Tanah" merupakan contoh produk hukum dalam rangka pembaharuan hukum pertanahan Indonesia serta untuk mewujudkan unifikasi hukum tanah nasional. Sebagaimana pendapat dari Boedi Harsono bahwa karena hak jaminan yang dikenal dalam UUPA adalah hak tanggungan, maka konversi hak hipotik tentunya menjadi hak tanggungan pula. ${ }^{1}$ Hal ini menunjukkan, bahwa lembaga jaminan atas tanah juga mengalami unifikasi. Anggapan bahwa hipotik sebagai lembaga yang berasal dari hukum tanah barat dan credietverband sebagai lembaga yang bergerak dalam suasana hukum adat masih tetap ada dan berlaku, maka berarti membiarkan tetap berlangsungnya dualisme dan perkembangan jaminan atas tanah, hal mana terang akan bertentangan dengan tujuan utama UUPA.

Keberadaan UUHT tersebut merupakan bagian yang tak terpisahkan dari pelaksanaan pasal 51 Undang_undang No.5 Tahun 1960 tentang Peraturan Dasar Pokok-Pokok Agraria (UUPA), dimana disebutkan bahwa hak tanggungan yang dapat dibebankan pada Hak Milik, Hak Guna Usaha dan Hak Guna Bangunan tersebut dalam pasal 25, 33 dan 39 diatur dengan Undang-Undang'. Disini telah diamanahkan lembaga hak jaminan yang kuat yang dapat dibebankan pada hak atas tanah sebagai pengganti lembaga Hipotik dan Creditverband. Keberadaan lembaga hipotik dan creditverband yang merupakan produk zaman kolonial Belanda dalam kenyataannya tidak dapat menampung perkembangan yang terjadi dalam bidang perbankan khususnya dalam bidang perkreditan dan jaminan kredit . dan juga dengan berlakunya UUHT maka ketentuan mengenai hipotik dan crdeitverband sebagaimana tersebut dalam Buku II BW sepanjang mengenai pembebanan hak tanggungan pada hak atas tanah beserta benda-benda yang berkaitan dengan tanah dinyatakan tidak berlaku lagi. Khusus mengenai hipotik

1 M.Jafar. 2001. Kepemilikan Atas Satuan Rumah Susun Sebagai Obyek Hak Tanggungan. Jurnal Hukum Toposantaro. Vo.2 No.5. Fakultas Hukum-Universitas Tadulako, H. 42 
yang tidak berlaku lagi hanya yang menyangkut pembebanan hipotik atas hak atas tanah beserta benda-benda yang berkaitan dengan tanah.

Dalam UUPA yang ditunjuk sebagai hak atas tanah yang dapat dijadikan jaminan kredit dengan dibebani hak tanggungan adalah hak milik, hak guna usaha dan hak guna bangunan, sebagai hak yang wajib didaftar dan menurut sifatnya dapat dipindahtangankan. Terhadap hak pakai dalam UUPA tidak ditunjuk sebagai objek hak tanggungan karena hak pakai tidak termasuk dalam hak-hak yang wajib didaftarkan sehingga tidak memenuhi asas publisitas untuk dapat dijadikan jaminan utang. Namun dalam perkembangannya dengan UUHT hak pakai atas tanah negarapun dapat didaftarkan dan hak pakai yang didaftarkan itu menurut sifat dan kenyataannya dapat dipindahtangankan.

UUPA berdasarkan atas hukum adat maka keberadaan UUHT pun didasarkan atas hukum adat. Salah satu asas yang terkandung dalam UUHT adalah asas pemisahan horizontal. Terhadap berlakunya hukum adat ini disyaratkan dalam pasal 5 UUPA yaitu hukum agraria yang berlaku atas bumi,air dan ruang angkasa ialah hukum adat sepanjang tidak bertentangan dengan kepentingan nasional dan negara, yang berdasarkan atas persatuan bangsa dengan sosialisme Indonesia serta dengan peraturan yang tercantum dalam undangundang ini dan dengan peraturan lainnya, segala sesuatu dengan mengindahkan unsur-unsur yang bersandar pada hukum agama.

Prinsip pemisahan horizontal inilah yang membedakan dengan hukum agraria dengan hukum perdata (BW) yang pada dasarnya menganut asas perlekatan yang memandang bahwa bangunan-bangunan dan/atau tanamantanaman yang tertancap di atas tanah merupakan bagian daripada tanah (Pasal 571, 1165 BW). Hukum tanah nasional yang berdasar hukum adat (asas horizontal) maka segala benda yang merupakan satu kesatuan dengan tanah yang dibebani hak tanggungan itu tidak dengan sendirinya dibebani pula dengan hak tanggungan yang dibebankan atas tanah tersebut. UUHT dalam penerapan hukumnya tidak menerapkan asas pemisahan horizontal secara mutlak Sebagaimana pendapat dari Sutan Remi Sjahdeni bahwa pembebanan hak tanggungan atas benda-benda yang berkaitan dengan dengan tanah hanya terjadi bila dengan tegas dinyatakan dalam Akta Pemberian hak tanggungan yang bersangkutan. ${ }^{2}$ Bila hal itu tidak dinyatakan dengan tegas (secara eksplisit), maka hak tanggungan hanya terjadi atas tanahnya saja.

\footnotetext{
${ }^{2}$ Sutan Remi Syahdeini. 1996. Hak Tanggungan, Asas-Asas Ketentuan Pokok Dan Masalah-Masalah Yang Dihadapi Oleh Perbankan (Suatu Kajian Mengenai UUHT). Airlangga University Press, Surabaya, H. 47
} 
Sehubungan dengan kebutuhan akan modal guna melaksanakan kegiatan usaha maka lembaga perkreditan berperan penting dalam pembangunan begitu pula dana yang disediakan adalah milik masyarakat, maka pemberian kredit tersebut perlu dilindungi. Untuk menghindari pengembalian dana yang macet sangat dibutuhkan adanya lembaga jaminan yang kuat yang dapat memberikan kepastian bagi pelunasan utang debitur (penerima kredit). Oleh Maria S.W.Sumardjono, dinyatakan bahwa karena kegiatan perkreditan tersangkut berbagai pihak maka dalam UU ini kepentingan berbagai pihak tersebut diperhatikan dan memperoleh keseimbangan dalam perlindungan serta kepastian hukumnya. ${ }^{3}$

Lembaga perkreditan seperti bank cenderung lebih menerima jaminan kebendaan maupun jaminan perorangan (personal guaranty), karena merupakan jaminan yang paling disukai dan menguntungkan kreditur adalah jaminan hak tanggungan (dahulu hipotik) oleh karena di dalam perjanjian ditentukan benda tertentu yang diikat perjanjian, dan obyek jaminan yang diutamakan adalah tanah sebab nilai tanah tidak pernah berkurang.

\section{PEMBAHASAN}

\section{A. Pengertian Hak Tanggungan}

Hak tanggungan adalah hak jaminan yang dibebankan pada hak atas tanah sebagaimana dimaksud dalam Undang-Undang No.5 Tahun 1960 tentang Peraturan Dasar Pokok-Pokok Agraria, berikut atau tidak berikut benda-benda lain yang merupakan satu kesatuan dengan tanah itu, untuk pelunasan utang tertentu yang memberikan kedudukan yang diutamakan kepada kreditur tertentu terhadap kreditur-kreditur lain. Adapun beberapa unsur pokok dari hak tanggungan adalah:

1. hak yaitu hak jaminan;

2. yang dibebankan atas tanah sebagai yang dimaksud oleh UUPA;

3. berikut atau tidak berikut dengan benda-benda yang merupakan satu kesatuan dengan tanah itu;

4. untuk pelunasan utang tertentu;

5. memberikan kedudukan yang diutamakan kepada kreditur tertentu terhadap kreditur yang lain.

3 Maria.S.W.Sumardjono. 1997. Prinsip Dasar dan Isyu Di Seputar UUHT. Jurnal Hukum Bisnis. Vol.1. Yayasan Pengembangan Hukum Bisnis, Jakarta, H. 37 
Hal di atas bila dibandingkan berbeda dengan hak hipotik, yang obyeknya tidak hanya tanah melainkan juga benda-benda yang tak bergerak atau tetap. Definisi hipotik dalam pasal 1162 BW yaitu hipotik adalah suatu hak kebendaan atas benda-benda tak bergerak, untuk mengambil penggantian daripadanya bagi pelunasan suatu perikatan. Unsur-unsur hipotik yaitu:

1. hipotik adalah suatu hak kebendaan;

2. obyek hipotik adalah benda-benda tak bergerak;

3. untuk pelunasan suatu perikatan.

Jadi, hak tanggungan merupakan jaminan atas tanah untuk pelunasan utang tertentu, yang memberi kedudukan diutamakan kepada kreditor tertentu terhadap kreditor-kreditor lainnya. Maksud dari kreditor diutamakan dari kreditor lainnya yaitu apabila debitor cidera janji, kreditor pemegang hak tanggungan dapat menjual barang agunan melalui pelelangan umum untuk pelunasan utang debitor. Kedudukan diutamakan tersebut tentu tidak mempengaruhi pelunasan utang debitor terhadap kreditor-kreditor lainnya. Hukum mengenai perkreditan modern yang dijamin dengan hak tanggungan mengatur perjanjian dan hubungan utang-piutang tertentu antara kreditor dan debitor, yang meliputi hak kreditor untuk menjual lelang harta kekayaan tertentu yang ditunjuk secara khusus sebagai jaminan (obyek hak tanggungan) dan mengambil pelunasan piutangnya dari hasil penjualan tersebut jika debitor cidera janji. Kreditor pemegang hak tanggungan mempunyai hak mendahulu daripada kreditor-kreditor yang lain ("droit de preference") untuk mengambil pelunasan dari penjualan tersebut. Kemudian hak tanggungan juga tetap membebani obyek hak tanggungan ditangan siapapun benda itu berada, ini berarti bahwa kreditor pemegang hak tanggungan tetap berhak menjual lelang benda tersebut, biarpun sudah dipindahkan haknya kepada pihak lain (“droit de suite”) (Boedi Harsono, 1999:402).

Hak-hak atas tanah yang ditunjuk oleh UUHT sebagai hak-hak atas tanah yang dapat dijadikan jaminan utang dengan dibebani hak tanggungan adalah hak milik, hak guna usaha, dan hak guna bangunan. Selain hak-hak tersebut hak pakai atas tanah negara yang sebelumnya dalam UUPA bukan merupakan obyek hak tanggungan. Dengan keluarnya UUHT No.4/1996 maka hak pakai wajib didaftarkan dan menurut sifatnya dapat dipindahtangankan dapat juga dibebani hak tanggungan. Selain itu rumah susun berikut tanah dan benda-benda yang merupakan satu kesatuan dengan bangunan juga dapat dibebani hak tanggungan. 


\section{B. Ciri-Ciri dan Sifat Hak Tanggungan}

Adapun ciri-ciri hak tanggungan adalah:

1. droit de prefenrence (pasal 1 angka 1 dan pasal 20 ayat (1) UUHT).

2. droit de suite (pasal 7 UUHT)

3. memenuhi asas spesialitas dan asas publisitas.

Asas spesialitas yaitu asas yang mewajibkan dalam muatan akta pemberian hak tanggungan harus mencantumkan ketentuanketentuan seperti ditegaskan dalam pasal 11 UUHT. Sedangkan asas publisitas yaitu asas yang mewajibkan didaftarkannya hak tanggungan pada kantor pertanahan setempat (pasal 13 UUHT).

4. mudah dan pasti pelaksanaan eksekusinya;

5. objek hak tanggungan tidak masuk dalam boedel kepailitan pemberi hak tanggungan sebelum kreditor pemegang hak tanggungan mengambil pelunasan dari hasil penjualan obyek hak tanggungan (pasal 21 UUHT).

Sedang sifat-sifat hak tanggungan antara lain:

1. Tidak dapat dibagi-bagi (pasal 2 UUHT)

Meskipun sifat hak tanggungan tidak dapat dibagi-bagi, artinya hak tanggungan membenani obyek secara utuh, namun sifat ini tidak berlaku mutlak dengan pengecualian dimungkinkan roya parsial, sepanjang diperjanjikan dalam Akta Pemberian Hak Tanggungan (APHT).

2. bersifat accesoir atau perjanjian buntutan/ikutan, maksudnya perjanjian jaminan utang atas hak tanggungan tidak berdiri sendiri karena ikut pada perjanjian pokok yaitu perjanjian utang-piutang, apabila perjanjian pokok hapus atau batal, maka otomatis perjanjian accesoir menjadi hapus pula.

Hak tanggungan tidak dapat berdiri sendiri tanpa didukung oleh suatu perjanjian (perjanjian kredit) antara debitor dan kreditor. Dalam perjanjian itu diatur tentang hubungan hukum antara kreditor dan debitor, baik menyangkut besarnya jumlah kredit yang diterima oleh debitor, jangka waktu pengembalian kredit, maupun jaminan yang nantinya akan diikat dengan hak tanggungan. Oleh karena hak tanggungan tidak dapat dilepaskan dari perjanjian kredit, itulah sebabnya maka hak tanggungan dikatakan accessoir (mengikuti) perjanjian pokoknya. Dalam menjalankan suatu perjanjian khususnya dalam perjanjian kredit, para pihak (debitor, kreditor) selalu dibebani dua hal yaitu hak dan kewajiban Oleh Subekti (1979:29) mengatakan suatu perikatan yang dilahirkan oleh suatu perjanjian, mempunyai dua sudut: sudut kewajiban-kewajiban (obligations) yang dipikul oleh suatu pihak dan sudut hak-hak atau manfaat, yang 
diperoleh oleh lain pihak, yaitu hak-hak menurut dilaksanakannya sesuatu yang disanggupi dalam perjanjian itu.

Kredit yang diberikan oleh kreditor mengandung resiko, maka dalam setiap pemberian kredit, bank tidak diperkenankan memberikan kredit tanpa ada suatu perjanjian tertulis. Itu sebabnya diperlukan suatu jaminan kredit dengan disertai keyakinan akan kemampuan debitor melunasi utangnya. Hal ini sesuai dengan ketentuan pasal 8 UU Perbankan No.7/1992 yang menyatakan dalam memberikan kredit, bank umum wajib mempunyai keyakinan atas kemampuan dan kesanggupan debitor untuk melunasi hutangnya sesuai yang diperjanjikan.

Objek Hak Tanggungan

Objek hak tanggungan adalah hak-hak atas tanah yang diatur dalam UUPA. Benda-benda (tanah) akan dijadikan jaminan atas suatu utang dengan dibebani hak tanggungan harus memenuhi syarat sebagai berikut:

1. dapat dinilai dengan uang;

2. harus memenuhi syarat publisitas;

3. mempunyai sifat droit de suite apabila debitor cidera janji;

4. memerlukan penunjukkan menurut UU.

Berkaitan dengan hal tersebut di atas yang dapat dijadikan obyek hak tanggungan adalah:

1. hak-hak atas tanah yang dapat dibebani hak tanggungan adalah:

a. hak milik

b. hak guna usaha

c. hak guna bangunan

2. hak pakai atas tanah Negara yang menurut ketentuan wajib didaftar dan menurut sifatnya dapat dipindahtangankan dapat juga dibebani hak tanggungan. Dijadikannya hak pakai sebagai obyek hak tanggungan merupakan langkah maju dalam hukum pertanahan kita juga bagi warga Negara asing menjadi pemegang hak pakai atas tanah Negara yang bila hak tersebut akan dijadikan jaminan disertai persyaratan bahwa modal yang diperoleh harus dipergunakan untuk kegiatan pembangunan di Indonesia. Pengawasan pemerintah terhadap WNA dalam pencapaian tujuan tersebut masih susah untuk dilaksanakan karena memang tidak ada penjabaran lebih lanjut dari maksud ketentuan persyaratan tersebut.

Menurut UU No.16 Tahun 1985 tentang Rumah Susun, pada pasal 12 ayat (1) ditegaskan "Rumah susun berikut tanah tempat bangunan itu berdiri serta benda lainnya yang merupakan atau kesatuan dengan tanah tersebut dpat dijadikan jaminan utang dengan: 
a. dibebani hipotik, jika tanahnya tanah milik atau hak guna bangunan.

b. Dibebani fiducia, jika tanahnya hak pakai atau tanah Negara, namun dengan keluarnya UUHT maka hak pakai tidak lagi dibebankan dengan fiducia tetapi dengan hak tanggungan (pasal 27 UUHT).

Selain obyek hak tanggungan seperti tersebut di atas, UUHT juga membuka kemungkinan pembebanan hak tanggungan atas tanah berikut bangunan dan tanaman yang ada diatasnya (pasal 4 ayat (4)), sepanjang memenuhi persyaratan sebagai berikut:

a. bangunan dan tanah yang bersangkutan merupakan satu kesatuan dengan tanahnya dan bangunan tersebut melekat pada tanah yang bersangkutan.

b. pembebanannya dinyatakan dengan tegas oleh pihak-pihak yang bersangkutan dalam Akta Pemberian Hak Tanggungan (APHT).

Ketentuan pasal 4 ayat (4) UUHT tersebut di atas sebagai konsekuensi dari penerapan asas pemilikan secara horizontal yang diambil dari hukum adat. Pemisahan tanah dengan benda-benda yang ada di atas tanah melalui asas pemisahan horizontal dapat dilakukan melalui pendaftaran. Oleh Mariam D. Badrulzaman (1997:34) dikatakan dengan pendaftaran bangunan (publikasi) maka benda itu dapat dijadikan obyek perikatan yang dilepaskan dari tanahnya. Arti yuridis dari pendaftaran di sini adalah ialah menciptakan hak kebendaan (real right) dan tidak dipergunakan dalam arti administrasi. Jika pemilik benda yang sudah terdaftar itu ingin melakukan perikatan terhadap bangunannya, dia tidak membutuhkan campur tangan dari pemilik tanah untuk ikut serta di dalam perjanjian yang diadakannya ataupun minta ijin dari pemilik tanah. Kemudian dalam pasal 4 ayat (5) UUHT dinyatakan apabila bangunan, tanaman, hasil karya sebagaimana dimaksud ayat (4) tidak dimiliki oleh pemegang hak atas tanah, pembebanan hak tanggungan atas benda-benda tersebut hanya dapat dilakukan dengan penandatanganan serta pada akta Pemberian Hak Tanggungan yang bersangkutan oleh pemilik atau yang diberi kuasa untuk itu olehnya dengan akta otentik.

Dalam kondisi demikian penerapan pasal 4 ayat (5) mungkin akan mengalami hambatan dalam pelaksanaannya, namun itulah yang dimaksud dalam penjelasan umum UUHT angka 6 yang memungkinkan penerapan asas pemisahan horizontal mengikuti perkembangan. Seperti yang dikemukakan oleh Maria S.W.Sumardjono (2001:125) "sesuai dengan perkembangan keadaan dan kebutuhan masyarakat sebagaimana nampak dalam praktek sehari-hari penerapan asas horizontal mengalami perkembangan". 
Nilai tambah dari asas horizontal bila dikaitkan besarnya jumlah kredit adalah perhitungan nilai benda yang dijaminkan tidak semata-mata diukur dari harga tanahnya saja, tetapi juga bangunan atau benda atau tanaman yang ada diatasnya yang dapat dinilai sehingga dapat meningkatkan nilai kredit. Khusus untuk tanah hak milik yang menurut sifat dan tujuannya tidak dapat dipindahtangankan misalnya tanah yang sudah diwakafkan dan tanah untuk keperluan peribadatan, walaupun didaftar namun karena sifat dan tujuannya tidak dapat dipindahtangankan, maka tidak dapat menjadi obyek hak tanggungan. Suatu obyek hak tanggungan dapat dibebani lebih dari satu hak tanggungan guna menjamin pelunasan utang. Benda yang dibebani hak tanggungan lebih dari satu ini melahirkan pemegang hak tanggungan peringkat pertama, peringkat kedua dan seterusnya. Apabila debitor wanprestasi, maka hak untuk memperoleh pelunasan utang debitor diberikan lebih dahulu pada kreditor peringkat pertama kemudian kedua dan seterusnya. Peringkat kreditor ditentukan berdasarkan tanggal pendaftarannya pada kantor pertanahan.

\section{Tata Cara Pembebanan Hak Tanggungan}

Tata cara pembebanan hak tanggungan terdiri atas dua tahap yaitu:

1. Tahap pemberian hak tanggungan yang dilakukan dihadapan Pejabat Pembuat Akta Tanah (PPAT), yang didahului dengan perjanjian utang piutang yang dijamin akta otentik yang dibuat oleh PPAT, pada tahap ini ada dua yaitu akta perjanjian utang piutang sebagai perjanjian pokok dan pembebanan jaminan (hak tanggungan) atas hak-hak atas tanah. Perjanjian ini accesoir.

2. Tahap pendaftaran yang dilakukan di kantor pertanahan kabupaten/kotamadya setempat. Pendaftaran dimaksudkan untuk memenuhi syarat publisitas dengan tujuan agar masyarakat mengetahui bahwa sebidang tanah telah dijadikan obyek jaminan atas hak tanggungan.

Hapusnya hak tanggungan dalam pasal 18 UUHT karena hal-hal berikut:

a. hapusnya piutang yang dijamin dengan hak tanggungan;

b. dilepaskannya hak tanggungan oleh kreditor pemegang hak tanggungan.

c. pembersihan hak tanggungan berdasarkan penetapan Ketua Pengadilan Negeri atas permohonan pembeli obyek hak tanggungan, jika hasil penjualan obyek hak tanggungan tidak cukup untuk melunasi semua utang debitor. Jika tidak diadakan pembersihan, hak tanggungan yang bersangkutan akan tetap membebani obyek yang dibeli. 
Hapusnya hak atas tanah yang dijadikan jaminan.Sebagaimana sifat accessoir dari hak tanggungan sebagai jaminan atas tanah, maka apabila perjanjian utang yang dijamin dengan hak tanggungan sebagai perjanjian pokok batal, dengan sendirinya hak tanggungan sangat tergantung adanya piutang yang

dijamin pelunasannya. Apabila piutang telah dilunasi atau hapus karena sebabsebab lain, maka seketika hak tanggungan yang bersangkutan menjadi hapus pula. Hapusnya hak tanggungan berdasarkan penetapan Ketua Pengadilan Negeri atas permohonan pembeli obyek hak tanggungan, jika hasil penjualan obyek hak tanggungan tidak cukup untuk melunasi semua utang debitor. Jika tidak diadakan pembersihan, hak tanggungan yang bersangkutan akan tetap membebani obyek yang dibeli. Hapusnya hak tanggungan karena hapusnya hak atas tanah yang dibebani tidak menyebabkan hapusnya piutang yang dijamin. Dalam hal hak atas tanah yang dibebani berakhir berakhir jangka waktunya (pasal 27 UUPA mengenai hapusnya hak milik, pasal 34 UUPA mengenai hapusnya hak guna usaha dan pasal 40 UUPA mengenai hapusnya hak guna bangunan) dan kemudian diperpanjang, hak tanggungan yang bersangkutan tidak menjadi hapus, karena hak atas tanah yang dibebani tetap berlangsung selama jangka waktu perpanjangan. Beda halnya jika hak atas tanah yang bersangkutan diperbaharui, karena hak atas tanah yang semula memang hapus. Kalau obyeknya semula tetap akan dijadikan jaminan harus dilakukan pembebanan hak tanggungan baru.

\section{PENUTUP}

Keberadaan lembaga jaminan (hak tanggungan) sangat menunjang dalam era pembangunan ekonomi, terutama dari pengusaha yang membutuhkan kredit untuk pengembangan usahanya . Perkembangan ekonomi dan perdagangan yang diikuti oleh perkembangan kebutuhan akan kredit dan pemberian fasilitas kredit memerlukan jaminan demi keamanan pemberian kredit. Oleh karena itu keberadaan hak tanggungan sebagai lembaga jaminan hak sangat mendukung, apalagi dengan masuknya investor asing ke Indonesia serta terbukanya kemungkinan bagi WNA/badan hukum asing untuk mendapat hak pakai atas tanah Negara dan menjadikannya sebagai jaminan untuk memperoleh modal/kredit di Indonesia guna menunjang kegiatan perekonomian di Indonesia. 


\section{DAFTAR PUSTAKA}

Boedi Harsono. 1999. Hukum Agraria Indonesia, Sejarah Pembentukan UndangUndang Pokok Agraria, Isi dan Pelaksanaannya. Djambatan, Jakarta.

M.Jafar. 2001. Kepemilikan Atas Satuan Rumah Susun Sebagai Obyek Hak Tanggungan. Jurnal Hukum Toposantaro. Vo.2 No.5. Fakultas HukumUniversitas Tadulako.

Mariam D.Badrulzaman. 1997. Posisi Hak Tanggungan Dalam Hukum Jaminan Nasional.Jurnal Hukum Bisnis. Vol.1. Yayasan Pengembangan Hukum Bisnis, Jakarta.

Maria.S.W.Sumardjono. 1997. Prinsip Dasar dan Isyu Di Seputar UUHT. Jurnal Hukum Bisnis. Vol.1. Yayasan Pengembangan Hukum Bisnis, Jakarta.

2001. Kebijakan Pertanahan Antara Regulasi dan Implementasi. Buku Kompas, Jakarta.

Subekti. 1979. Hukum Perjanjian. Cetakan VI. PT.Intermasa, Jakarta.

Sutan Remi Syahdeini. 1996. Hak Tanggungan, Asas-Asas Ketentuan Pokok Dan Masalah-Masalah Yang Dihadapi Oleh Perbankan (Suatu Kajian Mengenai $U U H T)$. Airlangga University Press, Surabaya. 